\title{
Erratum: How brain asymmetry relates to performance - a large-scale dichotic listening study
}

\author{
Marco Hirnstein $^{1 *}{ }^{*}$ Kenneth Hugdahl ${ }^{1,2,3}$ and Markus Hausmann ${ }^{4}$ \\ ${ }^{1}$ Department of Biological and Medical Psychology, University of Bergen, Bergen, Norway \\ ${ }^{2}$ Department of Radiology, Haukeland University Hospital, Bergen, Norway \\ ${ }^{3}$ Division of Psychiatry, Haukeland University Hospital, Bergen, Norway \\ ${ }^{4}$ Department of Psychology, Durham University, Durham, UK \\ *Correspondence: marco.hirnstein@psybp.uib.no
}

Edited and reviewed by:

Sebastian Ocklenburg, University of Bergen, Norway

Keywords: hemispheric asymmetry, lateralization, dichotic listening, task-performance, sex, age, handedness, verbal abilities

\section{An erratum on}

How brain asymmetry relates to performance - a large-scale dichotic listening study

by Hirnstein, M., Hugdahl, K., and Hausmann, M. (2014). Front. Psychol. 4:997. doi: 10.3389/fpsyg.2013.00997

Kenneth Hugdahl's second affiliation is Department of Radiology, Haukeland University Hospital, Bergen, Norway.

On page 1 the final sentence in the second column should read: "Moreover, individuals with lower degrees of language lateralization as determined with fMRI (van Ettinger-Veenstra et al., 2010) or magnetic resonance diffusion tensor imaging (Catani et al., 2007) performed better on tests assessing verbal abilities (van Ettinger-Veenstra et al., 2010) or verbal memory (Catani et al., 2007) than individuals with higher degrees of lateralization."

On page 7 the final sentence of the first column should read: "For the same reason van Ettinger-Veenstra et al. (2010) might have failed with a sample size of $n=16$ to find correlations between ear asymmetry and behavioral language tests in the nonforced condition of the Bergen DL task."

On page 8 the final paragraph of the discussion should read: "As far as language is concerned, however, stronger lateralization seems to be associated with better performance in verbal abilities (Boles et al., 2008; Chiarello et al., 2009; Everts et al., 2009; Barth et al., 2012, but see Catani et al., 2007; van Ettinger-Veenstra et al., 2010).”

\section{REFERENCES}

Barth, J. M., Boles, D. B., Giattina, A. A., and Penn, C. E. (2012). Preschool child and adult lateralisation and performance in emotion and language tasks. Laterality 17, 412-427. doi: 10.1080/1357650X.2011.626435

Boles, D. B., Barth, J. M., and Merrill, E. C. (2008). Asymmetry and perfor-mance: toward a neurodevelopmental theory. Brain Cogn. 66, 124-139. doi: 10.1016/j.bandc.2007.06.002

Catani, M., Allin, M. P. G., Husain, M., Pugliese, L., Mesulam, M. M., Murray, R. M., et al. (2007). Symmetries in human brain language pathways corre-late with verbal recall. Proc. Natl. Acad. Sci. U.S.A. 104, 17163-17168. doi: 10.1073/pnas.0702116104

Chiarello, C., Welcome, S. E., Halderman, L. K., and Leonard, C. M. (2009). Does degree of asymmetry relate to performance? An investigation of word recognition and reading in consistent and mixed handers. Brain Cogn. 69, 521-530. doi: 10.1016/j.bandc.2008.11.002

Everts, R., Lidzba, K., Wilke, M., Kiefer, C., Mordasini, M., Schroth, G., et al. (2009). Strengthening of laterality of verbal and visuospatial functions during childhood and adolescence. Hum. Brain Mapp. 30 473-483. doi: 10.1002/hbm.20523

van Ettinger-Veenstra, H. M., Ragnehed, M., Hallgren, M., Karlsson, T., Landtblom, A. M., Lundberg, P., et al. (2010). Right-hemispheric brain acti-vation correlates to language performance. Neuroimage 49, 3481-3488. doi: 10.1016/j.neuroimage.2009.10.041

Received: 15 January 2014; accepted: 16 January 2014; published online: 31 January 2014.

Citation: Hirnstein $M$, Hugdahl $K$ and Hausmann $M$ (2014) Erratum: How brain asymmetry relates to performance - a large-scale dichotic listening study. Front. Psychol. 5:58. doi: 10.3389/fpsyg.2014.00058

This article was submitted to Cognition, a section of the journal Frontiers in Psychology.

Copyright () 2014 Hirnstein, Hugdahl and Hausmann. This is an open-access article distributed under the terms of the Creative Commons Attribution License (CC BY). The use, distribution or reproduction in other forums is permitted, provided the original author(s) or licensor are credited and that the original publication in this journal is cited, in accordance with accepted academic practice. No use, distribution or reproduction is permitted which does not comply with these terms. 